\title{
Taking Dominion in a Christian Nation
}

\section{North American Political Theology in an African Context}

\author{
Naomi Haynes | ORCID: 0000-0001-6909-7574 \\ University of Edinburgh, Edinburgh, Scotland, UK \\ Naomi.Haynes@ed.ac.uk
}

\begin{abstract}
This article traces some of the North American theological influences on contemporary Christian nationalism in Zambia. Beginning with an overview of key tenets of Christian Reconstruction and the New Apostolic Reformation, I show how these movements have influenced the writing of some key players in Zambia's Christian nationalist project. I also demonstrate how these authors have modified the Western ideas that have shaped their thought. This analysis responds to calls in the anthropology of Christianity for better documentation of the various forms Christian nationalism takes around the world, perhaps especially outside the West. It also challenges easy arguments about the influence of Western Christian activists on Christian politics in Africa by foregrounding the agency of local writers and theologians, even as they engage with theological ideas that originated in the West.
\end{abstract}

\section{Keywords}

Christian nationalism - Zambia - political theology - transnationalism - Christian Reconstruction - New Apostolic Reformation

These days, one does not have to look far to find critiques blaming Christian activism in Africa on Western religious influences. The most obvious example is anti-LG BT legislation in several countries, which, many argue, is more reflective of Western concerns than of those of African Christians themselves. As pastor and activist Kapya John Kaoma puts it, "Anti-gay legislation and constitutional prohibitions are often drafted by Africans who are 'ideologically mentored' and trained by U.S. conservatives, and the bills reflect American, not 
African realities." While there is no disputing the clear links between Western, particularly North American, conservative Christianity and these sorts of political developments in Africa, we should be skeptical of arguments that suggest that foreign ideas have been taken up whole cloth without being transformed to reflect local concerns. ${ }^{2}$ Nor should we forget that the currents of theological influence flow in more than one direction. ${ }^{3}$ Building on these observations about how theological — and specifically political-theological — concepts circulate and are transformed transnationally, I aim in this article to work through the adoption of a few Western ideas that have figured in Christian nationalism in contemporary Zambia. Specifically, I explore the influence of two prominent strains of what is sometimes called "dominionism," twentieth-century Christian Reconstructionism, and the more recent New Apostolic Reformation. By exploring the application of these Western theological traditions in an African context, my analysis speaks to variations in the Christian political-theological nexus in both parts of the world.

Let me begin by clarifying what I mean by "Christian nationalism." With this term I am referring to the broad but nevertheless explicit convergence of visions of national identity or destiny with narratives of Christian election or providence. ${ }^{4}$ In an important article about the variety of forms that Christian nationalism takes, Jon Bialecki has highlighted "the unfixed nature of the nationalist imagination"5 as key to understanding the differences among Christian nationalist projects around the world. Toward this end, he demonstrates how particular features of Christianity-eschatology, differentiation, boundary-making — can, under particular circumstances, "crystalize" in a Christian nationalism that, while always uniquely inflected by its social or cultural context, nevertheless shares some common core characteristics. The most notable of these, in Bialecki's analysis, is a kind of Nietzschean ressentiment through which Christians come to think of themselves as both an entitled majority and an embattled minority. ${ }^{6}$

1 Kapya John Kaoma, Colonizing African Values: How the U.S. Christian Right is Transforming Sexual Politics in Africa (Somerville, MA: Political Research Associates, 2012), 9.

2 Joel Robbins, "The Globalization of Pentecostal and Charismatic Christianity," Annual Review of Anthropology 33 (2004): 117-143, 118.

3 See for example, Jon Bialecki, "The Third Wave and the Third World," Pneuma 37 (2015):177200.

4 Here my thought follows that of Stephen Backhouse. See Stephen Backhouse, Kierkegaard's Critique of Christian Nationalism (Oxford: Oxford University Press, 2011).

5 Jon Bialecki, "Eschatology, Ethics, and Ethnos: Ressentiment and Christian Nationalism in the Anthropology of Christianity," Religion and Society: Advances in Research 8 (2011):42-61, 42.

6 Bialecki, "Eschatology, Ethics, and Ëthnos," 49-51. 
Bialecki's argument turns on his research with North American charismatic Evangelicals, but his broader aim is to "catalyze debate and encourage the kind of fine-grained ethnographic discussions that can flesh out the contours of ... the Christian nationalist problem." ${ }^{7}$ Following Bialecki's lead, my aim in this article is to do precisely that. Leaving aside for the moment the particular problem of applying Nietzschean concepts to a postcolonial African context, in the discussion that follows I explore "the contours of ... the Christian nationalist problem" in contemporary Zambia by examining some of the historical, transcultural influences that have shaped it into what it is today. The two key issues that emerge from this analysis are, first, a unique understanding of the limitations of the secular liberal state, and, second, the evolving relationship between Christian adherence and expectations for economic development. When it comes to documenting the broad range of forms that Christian nationalism takes, Zambia is especially good to think with. As the only self-declared Christian nation in Africa, and as such the most fully realized expression of Christian nationalism on the continent, Zambia has long served as a sort of "laboratory for studying ... a certain kind of evangelical politics in action." ${ }^{\prime 2}$ While the country is therefore something of a limit case, the view from its position of relative extremity affords an important perspective on broader religious trends visible across Africa and beyond.

Zambia was initially declared a Christian nation by pentecostal president Fredrick Chiluba in 1991. Five years later "the declaration," as it is often known, was enshrined in the preamble to the Zambian constitution, where it remains to this day. ${ }^{9}$ As I have demonstrated in greater detail elsewhere, the theological underpinnings of the declaration were structured by pentecostal practice, particularly positive confession and the productive exchanges associated with the prosperity gospel..$^{10}$ Most Zambian Pentecostals regard the declaration as a sacred covenant between God and their country, the key to future prosperity and the guarantor of domestic peace. This emphasis on the declaration as covenant, which I return to below, is fundamental to the way believers understand the role of national leadership, particularly the responsibilities of

7 Bialecki, "Eschatology, Ethics, and Ëthnos," 46.

8 Paul Freston, Evangelicals and Politics in Asia, Africa and Latin America, (Cambridge: Cambridge University Press, 2004), 154.

9 For further discussions of the declaration see Paul Gifford, "Chiluba's Christian Nation: Christianity as a Factor in Zambian Politics 1991-1996," Journal of Contemporary Religion 13 (1998): 363-381; Isabel Apawo Phiri, "President Frederick J.T. Chiluba of Zambia: The Christian Nation and Democracy," Journal of Religion in Africa 33 (2003): 401-428.

10 Naomi Haynes, "Zambia Shall be Saved!' Prosperity Gospel Politics in a Self-Proclaimed Christian Nation," Nova Religio 19 (2015): 5-24. 
the president, which hinge on maintaining the covenant established by the declaration. ${ }^{11}$ Chiluba's vision of what it meant for Zambia to be a Christian nation shaped a number of policy initiatives during his presidency, including the establishment of diplomatic ties with Israel (like many of their counterparts elsewhere, Zambian Pentecostals are Zionists); the issue of diplomatic passports to prominent pastors (who were to be "ambassadors" of the Christian nation); and large evangelistic crusades featuring international preachers, presided over by the president and supported by state funds. In addition, the Chiluba government relaxed the regulations for registering churches and securing land for church buildings, a move that disproportionately favored Pentecostals. $^{12}$

Both ideologically and practically, then, the declaration has been a largely pentecostal concern. Meanwhile, Christians from other denominations have been vocal in their criticisms of the declaration; in the case of Catholics, for example, the argument is that a close alliance between Christianity and the government hinders the capacity of the church to speak critically when confronted with abuses of state power, such as Chiluba's attempt to alter the constitution so that he could run for an additional term as president, a move that his pentecostal peers broadly supported. ${ }^{13}$ Studies of Christian nationalism in Zambia like the one I offer here are therefore of particular interest to scholars of Pentecostalism.

Before going any further, one brief observation about the terminology of this article is in order. While common in journalistic discussions of North American Christianity, the term "dominionism" has been rejected by proponents of the theology examined here as well as by scholars studying so-called "dominionist" movements. As Michael J. McVicar demonstrates in an excellent history of the word, ${ }^{14}$ "dominionism" was a label coined by commentators, first Christian, then secular-liberal, who were trying to diagnose what they saw as a set of worrisome theological developments alongside the rise of the Moral Major-

11 Naomi Haynes, “Why Can't a Pastor be President of a Self-Proclaimed 'Christian Nation'?: Pentecostal Politics as Religious Mediation." Political and Legal Anthropology Review 41 (2018): 6o-74.

12 Elizabeth Sperber and Erin Hern, "Pentecostal Identity and Citizen Engagement in SubSaharan Africa: New Evidence from Zambia," Politics and Religion 11 (2018): 830-862.

13 Marja Hinfelaar, "Debating the Secular in Zambia: The Response of the Catholic Church to Scientific Socialism and Christian Nation, 1976-2006," in Christianity and Public Culture in Africa, ed. Harri Englund (Athens: Ohio University Press, 2011).

14 Michael J. McVicar, "Let Them Have Dominion: Dominion Theology and the Construction of Religious Extremism in the US Media," The Journal of Religion and Popular Culture 25 (2013): 120-145. 
ity in the U.S. in the 1970s and 1980s. Today, McVicar argues, the term serves primarily as "a screen on which critics project myriad competing interpretations of the proper place of religion in American society" rather than a precise classification of a theological movement. ${ }^{15} \mathrm{He}$ therefore suggests that scholars avoid it. Following McVicar's careful reading, I do not make much use of the term "dominionism" here, preferring instead to use the emic labels "Christian Reconstruction" and "New Apostolic Reformation" to refer to Western theologies and "Christian nationalism" or "Christian nationalist activists" in reference to Zambia.

The argument of this article draws on my significant experience studying Zambian Christianity, primarily in its pentecostal forms. Building on long-term field research in independent pentecostal congregations on the Copperbelt province, ${ }^{16}$ in 2017 I began a new research project focused on recent government efforts to "actualize" the declaration of Zambia as a Christian nation. This topic has required me to combine participant-observation in government offices with interviews and interactions with church leaders, analysis of new and traditional media, and textual studies like that which informs this article. This mixed-methods research has in turn allowed me to take a much broader approach to the question of Christian nationalism in Zambia, for example by tracing the transnational theological influences that have shaped the movement, a task to which I now turn.

\section{Some Theological Roots of Contemporary Zambian Christian Nationalism: Christian Reconstruction and the New Apostolic Reformation}

The first Western movement that concerns us is Christian Reconstruction. The undisputed father of Christian Reconstruction was Rousas John Rushdoony, ${ }^{17}$ an Armenian-American conservative Calvinist born in 1916 and brought up in Fresno County, California by Presbyterian parents. His father, a survivor of the Armenian genocide, was a pastor, and the junior Rushdoony also discerned a call to ministry. His early years as a missionary on a Native American

\footnotetext{
15 McVicar, "Let Them Have Dominion," 133.

16 See Naomi Haynes, Moving by the Spirit: Pentecostal Social Life on the Zambian Copperbelt (Berkeley: University of California Press, 2017).

17 For an excellent intellectual history of Christian Reconstruction focused on Rushdoony, see Michael J. McVicar, Christian Reconstruction: R.J. Rushdoony and American Religious Conservatism (Chapel Hill, NC: University of North Carolina Press, 2016).
} 
reservation in Nevada cemented a libertarian commitment that he combined with his unique reading of Reformed theology to frame what he called "Christian Reconstruction." Christian Reconstruction advocated for the restoration of biblical—that is, primarily Old Testament—law, or "theonomy," a cause that led to some of Rushdoony's most infamous positions, including advocacy of the death penalty for homosexuals, witches, and recalcitrant youth.

Historian Molly Worthen argues that the animating concern of Rushdoony's thought was cosmological differentiation. ${ }^{18}$ Rushdoony's Chalcedon Foundation was named for the Council of Chalcedon of $451 \mathrm{CE}$, which ruled that Jesus was at once fully divine and fully human. Rushdoony built on this point to argue for a hard, qualitative difference between God and humanity. In addition, as a staunch Calvinist Rushdoony adhered to the doctrine of dual predestination, arguing that even before their birth all humans are destined either for heaven or hell. The world is therefore structured around fundamental hierarchical distinctions between the divine and the human and between the saved and the damned. In view of this steeply graded spiritual topography, Rushdoony developed two of his axiomatic principles: first, that there is no such thing as neutrality (an idea he took from Calvinist theologian Cornelius van Til), and second, that various "spheres" of human life (the family, the church, the government) are each "sovereign" only over their particularly allocated jurisdiction. Both of these ideas have been important to Zambian Christian political theology and are worth unpacking here.

For Christian Reconstructionists, neutrality of the sort advocated by John Rawls's notion of "reasonable pluralism," wherein public discourse must be framed in terms of neutral, agreed-upon values, ${ }^{19}$ is a theological and cosmological impossibility. According to Rushdoony and his followers, the entire world is under either divine or human control, and all political and social positions or institutions are therefore either advancing God's cause or advancing its opposite, what Rushdoony identified as the cause of "humanism." This meant that there could never be a true separation of church and state any more than there could be a secular state or public sphere. ${ }^{20}$ It was therefore up to a population to decide whether they would adhere to the higher order of divine will or the lower order of human purposes and plans. ${ }^{21}$ It is in view of his disavowal of

18 Molly Worthen, "The Chalcedon Problem: Rousas John Rushdoony and the Origins of Christian Reconstructionism," Church History 77 (2008): 399-437.

19 John Rawls, Political Liberalism (New York: Columbia University Press, 1993).

20 Julie Ingersoll, Building God's Kingdom: Inside the World of Christian Reconstruction (New York: Oxford University Press, 2015), 21.

21 Rousas John Rushdoony, Christianity and the State (Vallecito, CA: Ross House Books, 1986), 84. 
neutrality that Rushdoony came to his "fundamental claim" that "religious toleration is un-Christian," ${ }^{22}$ since tolerance ultimately amounted to ceding what might otherwise be Christian territory to humanist influence.

Rushdoony's commitment to the ontological distinction between God and humans and between the saved and the damned also informed his concept of "sphere sovereignty," which Rushdoony borrowed from the nineteenth-century Dutch theologian Abraham Kuyper. For Kuyper and for Rushdoony, sphere sovereignty "meant that every realm of human society—church, academia, et cetera-ought to be sovereign within its own sphere of influence, brooking government intrusion only to resolve disputes or in the case of one sphere's failure to meet its social responsibilities." ${ }^{23}$ Importantly, these spheres were not all seen as equal in their influence. In his exposition on Saint Paul's injunction to pray for those in authority, ${ }^{24}$ Rushdoony points out that in offering these prayers the Christian operates from a position of superiority to which earthly rulers are ultimately beholden. As he puts it, in the biblical text "the king is treated as a needy soul, and the praying Christian as a higher power who intercedes with the Great King for him!"25

Rushdoony's ideas have been influential in American conservative Protestantism even though many contemporary Christians have never heard his name. While his role in shaping the ideology of the Moral Majority is clear, ${ }^{26}$ he ultimately disapproved of their methods. As a libertarian, Rushdoony was skeptical of Christian political activism, emphatic in his insistence that the government ought to have little or no control over the affairs of individuals and families. His vision of social transformation turned on the aggregate effect of personal or small-scale changes rather than on organized political interventions. "After personal self-government is brought into line with God's law, then each family unit will adhere, and only then will broader social change begin, culminating in the peaceful implementation of God's law by churches, schools, and a limited state, each in their respective spheres." ${ }^{27}$ It is through this cumulative process that Christian Reconstruction aimed to expand the influence of Christianity - and by extension the "reign" of Jesus Christ—which is why it gets lumped together with other so-called "dominionist" theologies. Much of Christian Reconstructionism turns on a particular reading of Genesis 1:26-

\footnotetext{
22 Worthen, "The Chalcedon Problem," 435.

23 Worthen, "The Chalcedon Problem," 414; see also Ingersoll, Building God's Kingdom, 50-52.

24 1Timothy 2:1-2.

25 Rushdoony, Christianity and the State, 145.

26 McVicar, Christian Reconstruction, 145.

27 Worthen, "The Chalcedon Problem," 425.
} 
28, God's command to Adam and Eve to "fill the earth and subdue it." In view of this mandate, Rushdoony argued that "Christians can become 'dominion men,' who 'take dominion' over the planet and 'reconstruct' all of life according to Old Testament law."28 A similar aim animates the New Apostolic Reformation, a movement that has also contributed considerably to political theological thought in Zambia.

The New Apostolic Reformation (NAR) is a diffuse Christian movement made up of large collections of churches aligned under particular apostolic figures. ${ }^{29}$ The late C. Peter Wagner, former professor at the Fuller Seminary School of World Mission in Pasadena, California, is usually regarded as the intellectual architect of NAR; he coined the term "New Apostolic Reformation" in a book that makes use of the term in the title ${ }^{30}$ and was instrumental in articulating the aims and scope of the movement. Wagner's choice of the word "Reformation" is instructive, as he believed that NAR represented a paradigm shift in ecclesiastical practice and governance on a par with the Protestant Reformation. Despite his influence, Wagner insisted that neither he nor anyone else was at the "helm" of NAR, an intentionally acephalous and disparate movement characterized by personal connections, semiformal agreements, and dense relational networks. ${ }^{31}$

The lack of a centralized authority structure in NAR belies the movement's hallmark commitment to "apostolic" leadership. NAR is often described as a restoration of the "five-fold" ministry described in Ephesians 4:11, which identifies five offices of church leadership: apostles, prophets, evangelists, pastors, and teachers. Each one of these offices represents "an authorization to engage in an arena of activity that is an empowerment as well," a "particular endowment" that inheres uniquely in those called to be apostles, pastors, and so forth. ${ }^{32}$ Wagner argued that the offices represented by the fivefold ministry were hierarchically arranged in a "divine order" that put apostles first, with prophets following closely behind in an apostolic-prophetic alliance with the power to shape and reprimand local church leaders (i.e. pastors and teach-

28 McVicar, "Let them have Dominion," 122.

29 Peter Althouse and Robby Waddell, eds, "The New Charismatic Networks and Other Theological Matters," Pneuma 38, nos. 1/2 (2016): 1-4.

30 C. Peter Wagner. Churchquake! How the New Apostolic Reformation Is Shaking Up the Church as We Know It (Ventura, CA: Regal, 1999).

31 Michael Wilkinson, "Charismatic Christianity and the Role of Social Networks," Pneuma 38, nos. 1/2 (2016): 33 .

32 Jon Bialecki, "Apostolic Networks in the Third Wave of the Spirit," Pneuma 38, nos. 1/2 (2016): 3 . 
ers). ${ }^{33}$ This emphasis on a divinely ranked set of church offices, which carries echoes of Christian Reconstructionism's model of sphere sovereignty, gives the NAR a strong division of labor. It also informs the arrangements among individual congregations and ministries associated with NAR, which often include the religious equivalent of noncompetition agreements, with leaders committing not to impinge on one another's spiritual territory. ${ }^{34}$ As Wagner described it, "Apostles are not in competition with each other, they are in cahoots." ${ }^{35}$

One of the central aims of NAR's vision of church governance and practice is cultural change and, more specifically, creating "a society in which evangelical Christian values predominate." ${ }^{36}$ This change relies more on the quality of Christian influence than of its quantity. To summarize an argument put forward by Os Hillman, in the NAR's model of social transformation the work of cultural change has historically been carried out by a very small number of people"no more than three thousand change agents" across all of human history. "That is why," he goes on,

we must realize that making more converts will not necessarily change culture. It is important to have conversions, but it is more important to have those who are converted operate at the tops of the cultural mountains from a biblical worldview ... It doesn't matter if the majority of the culture is made up of Christians. It only matters who has the greatest influence over that cultural mountain. ${ }^{37}$

Hillman's reference to "cultural mountains" is a nod to one of NAR's key heuristics, the "Seven Mountains of Influence": Arts and Entertainment, Business, Education, Family, Government, Media, and Religion. ${ }^{38}$ According to several writers, ${ }^{39}$ the notion that influence was organized according to these seven mountains was simultaneously revealed to two prominent U.S. evangelical

33 C. Peter Wagner, "The New Apostolic Reformation Is Not a Cult," Charisma (2011).

34 Wilkinson, "Charismatic Christianity."

35 Wagner, "The New Apostolic Reformation."

36 John Weaver, The New Apostolic Reformation: History of a Modern Charismatic Movement (Jefferson, NC: McFarland, 2016), 146.

37 Os Hillman, "How Christians Can Change Our Culture," The Christian Post, May 24, 2013, https://www.christianpost.com/news/how-christians-can-change-our-culture.html; accessed May 3, 2021.

38 Also sometimes reconfigured to include military by combining arts and entertainment.

39 For example, Generals International, "The Seven Mountains of Cultural Influence," https:// www.generals.org/rpn/the-seven-mountains/; last accessed February 20, 2020, no longer available. 
leaders ${ }^{40}$ in 1975. The idea of the Seven Mountains has since spread widely in Christian circles and found a particular platform in NAR. Central to the NAR vision is the need to place Christians in "divinely strategic" positions on each of these "mountains" as a means of changing culture to reflect the Christian values. ${ }^{41}$ When Christians take up their position on, for example, the Mountain of Arts and Entertainment, "secular artists will begin to take their cues from the kingdom of God as it manifests through His children. They will add their lyrics to our music, rather than the other way around, as it has been for much too long." 42

The model of social change employed by NAR is in some respects different from that of Christian Reconstruction. Rushdoony, in particular, would not have countenanced Christian efforts to effect significant influence through government or education. More broadly, as we have seen, in the framework of Christian Reconstruction social transformation is episodic, brought about through the combined efforts of individual families and congregations. In contrast, the Seven Mountains model of the NAR emphasizes the roles of both key institutions and elite actors, putting more stock in the top-down efforts of a select few to trickle down into society more generally. Despite these differences, however, both movements have made it their mission to effect cultural and social transformation beyond the four walls of the church, which is why both NAR and Christian Reconstruction figure in discussions of so-called "dominionist" theology. The tension between these models of cultural change has also informed Christian social engagement in Zambia, ${ }^{43}$ although, as we will see, this is not the only way in which ideas taken from Christian Reconstruction and NAR have shaped the thought of those guiding Zambia's Christian nationalist project.

\section{Making Zambia a Christian Nation}

Turning our attention to Zambia, I want to look at two short books written by and for key players in the country's ongoing Christian nationalist project. Each

\footnotetext{
40 Bill Bright, founder of Campus Crusade for Christ (later rebranded as "Cru”) and Loren Cunningham, founder of Youth with a Mission.

41 Johnny Enlow, The Seven Mountain Prophecy: Unveiling the Coming Elijah Revolution (Lake Mary, FL: Creation House, 2008), 10.

42 Enlow, The Seven Mountain Prophecy, 15 o.

43 Also Naomi Haynes, "Concretizing the Christian Nation: Negotiating Zambia's National House of Prayer," Comparative Studies of South Asia, Africa, and the Middle East 41 (2021): $166-174$.
} 
of them cites the influences of Christian Reconstruction or NAR - specifically the work of Rushdoony on the one hand and the Seven Mountains model on the other-in developing their arguments about what it means for Zambia to be a Christian nation. The first book was written by Dr. Catherine Mukuka, a distinguished medical doctor and Pentecostal with an abiding interest in law (her sister is a judge). I first heard of her book in 2018 during a presentation by Zambia's then-Secretary to the Cabinet, Dr. Roland Msiska. Speaking to hundreds of assembled church leaders at Lusaka's Anglican Cathedral of the Holy Cross, Dr. Msiska encouraged everyone to read Dr. Mukuka's book. Inspired by this recommendation I tracked it down at a local mall; ${ }^{44}$ several months later I was able to locate Dr. Mukuka as well, and she agreed to meet me so I could talk to her about her book. Dr. Mukuka and I met in November 2018 at an upmarket coffee shop in Lusaka. We sat in fake leather armchairs sipping bottled water out of wine glasses; all around us the usual crowd of expatriates took up most of the other tables, each with a laptop and iced coffee in reach. Dr. Mukuka was fashionably dressed in the casual attire of a semiretired professional womana loose blazer and trousers with trendy metallic sandals. Her close-cropped hair was graying at the temples, and purple-rimmed glasses balanced on her nose.

Dr. Mukuka explained to me that she had written and self-published her book, A Christian Nation versus a Secular State: The Making of a Constitution, ${ }^{45}$ after first making a thirteen-page submission to the 2005 Constitutional Review Commission (CRC) in support of the declaration. While the CRC had received far more submissions in support of the declaration, they had also heard from a substantial number of parties who opposed its inclusion in the revised constitution, and had in an interim report stated that they would stand with the minority on this issue. In addition to the possibility that the declaration might be removed from the preamble of the constitution (which ultimately did not happen), Dr. Mukuka was also concerned that the document seemed to contradict itself, since several articles in the body of the document described Zambia as a secular state. These two issues-the possible removal of the declaration and its contradiction in subsequent articles of the constitution-provide the background for Mukuka's book. During our interview I asked Dr. Mukuka about the influences that shaped her argument, particularly Rushdoony, whom she

44 Despite this high-profile recommendation, I have no way of knowing how widely read Dr. Mukuka's book has been. It is reasonably easy to find in Lusaka, which boasts several large book stores that carry local titles alongside international bestsellers. However, books are expensive, and therefore largely inaccessible.

45 Catherine Mukuka, A Christian Nation Versus a Secular State:The Making of a Constitution (Lusaka: Abiyah Publishing House, 20o6). 
quotes at length throughout the text. She explained that while writing the book she had basically no internet access, and therefore had to rely on whatever books she had available, which were also limited. She stumbled upon most of her sources when visiting her sister on the Copperbelt, where she met a young man who was selling Christian books. While she didn't describe his trade in detail, I pictured his business like that of the informal booksellers I knew during my previous fieldwork on the Copperbelt - a hodgepodge of wares from textbooks to paperback novels, each marked with a handwritten price tag and spread on the sidewalk in the shade of a downtown office building. From this trader she bought several volumes that became the core references for her book, including Rushdoony's Philosophy of the Christian Curriculum, Christianity and the State, Law and Liberty, and Institutes of Biblical Law, as well as a Catholic encyclopedia. Reading these books didn't so much transform her thought as translate it, Dr. Mukuka explained, and she felt that the authors gave her a language to talk about what she already believed. However, as we will see, there are points where her argument diverges from the Reconstructionist sources that inform her writing.

Dr. Mukuka's argument hinges on what she identifies as a homology among secularism, humanism, and Satanism. Mukuka gets her definition of secularism from an array of sources, including the Catholic encyclopedia and publications by humanist organizations in the UK and the US. Drawing directly on Rushdoony, she goes on to argue that secularism is at bottom "a religion" with "its own concept of what is evil and forbidden and also what is permitted."46 From this point, however, her thought begins to depart from Rushdoony's rejection of neutrality in a direction shaped more by African Pentecostalism than by American Christian Reconstructionism. While Pentecostals also maintain that there is no neutral territory in the cosmos, they differ from Reconstructionists in their understanding of how this territory is divided. To wit, whereas Rushdoony saw the world as under the control either of God or of sinful humanity, the central dualism of pentecostal cosmology divides the universe into the territory of God and the territory of Satan..$^{47}$ For Pentecostals like Dr. Mukuka, anything that is not expressly Christian is effectively satanic-for example, I have heard Zambian Pentecostals describe Hindus as "Satanists." In view of this established dualism, Mukuka argues that since the tenets of secularism are

46 Mukuka, A Christian Nation, 23.

47 Jörg Haustein, "Embodying the Spirit(s): Pentecostal Demonology and Deliverance Discourse in Ethiopia," Ethnos 76 (2011): 534-552; Adriaan S. van Klinken, "Gay Rights, the Devil and the End Times: Public Religion and the Enchantment of the Homosexuality Debate in Zambia," Religion 43 (2013): 526-528. 
not biblical, "it can only be concluded that [secularism] is a religion of Satan. Clearly the god of secular humanism is Satan. This is why its statements of belief are anti-Christian and anti-the Bible."48

Mukuka makes a similar point in her discussion of humanism, a term that has a specific historical connotation in Zambia. The country's first president, Kenneth Kaunda, developed an ideology over the course of his nearly thirty years in power that he called "humanism." ${ }^{49}$ A mixture of socialism and the African concept of "ubuntu," Kaunda's brand of humanism was promoted as Zambia's national philosophy, taught in schools, and used as a guide for government initiatives. In contrast to some other Zambian Christian writers, ${ }^{50}$ Mukuka (whose personal copy of Kaunda's short book on humanism was autographed, thanks to the efforts of an aunt who worked in the president's office) makes no distinction between Kaunda's humanism and that of Western secular humanist activists, which allows her to draw an easy parallel first between humanism and secularism and, by extension, between humanism and the devil. Mukuka is not the only Pentecostal of her generation to make such strong accusations against Zambia's first president. In the 1980s, Kaunda's close relationship with the guru Dr. M.A. Ranganathan concerned many Christians, who argued in the Zambian press that the president had effectively forged an alliance with the devil by exploring Eastern religion. ${ }^{51}$ In Dr. Mukuka's telling, when Kaunda made humanism the national philosophy of Zambia, he made a spiritual, covenantal move that would be undone only by the declaration of Zambia as a Christian nation..$^{52}$ Before that, "Zambia was ... under the god of humanism who we know to be Satan."53

By describing the declaration as a covenant that undid a previous pact with the devil, Dr. Mukuka is appealing to what we have already identified as an established pentecostal understanding of the declaration as a divine agreement between God and the nation. This framing was explicitly used by Chiluba,

48 Mukuka, A Christian Nation, 23.

49 Kenneth David Kaunda, Humanism in Zambia and a Guide to Its Implementation (Lusaka Division of National Guidance, 1974).

$5^{\circ}$ See, for example, Derrick Muwina Muwina, Kenneth Kaunda's Philosophy of Christian Humanism in Africa from the Perspective of Christian Ethics (PhD diss., School of Theology, Boston University, 2018).

51 See Gifford, "Chiluba's Christian Nation," 364.

$5^{2}$ More recently, a similar point has been made by pentecostal writer Chisala Kateka, who observes that under Kaunda Zambia followed "the philosophy of humanism (an antibiblical philosophy)." See Chisala Kateka, Let Us PRAY for Zambia and Let His Kingdom Come (Lusaka: self-published, n.d.), 34 .

53 Mukuka, A Christian Nation, 38 . 
who first announced the declaration as a "covenant with the living God." In the same television broadcast, Chiluba also repented "on behalf of the nation" for the country's "idolatry, witchcraft, the occult [sic], immorality, injustice, and corruption," ${ }^{54}$ thereby breaking any previous spiritual agreements made by President Kaunda. In the light of this framing, subsequent discussions of political change among Zambian pentecostal laypeople, and particularly the prospect of a new president, have often been articulated in covenantal terms. ${ }^{55}$ This suggests that the theological structure of the declaration established by Chiluba extends both backward and forward in time, recasting the Kaunda era as one of a diabolical covenant and imagining any future government as either reaffirming or removing the divine covenant established by the declaration. ${ }^{56}$ In her critique of Kaunda's humanism, then, Dr. Mukuka draws on a locally specific articulation of Pentecostalism's well documented dualism, and in so doing reconfigures a central heuristic of North American Christian Reconstruction - the bifurcation of the cosmos into territories under divine or human control—in Zambian terms.

The second book, Embracing our Destiny: Redeeming Zambia in Righteousness-Africa's Tithe, ${ }^{57}$ is authored by a group of people comprising the Zambia branch of the international "Africa Arise" movement, founded by a pentecostal pastor in Ethiopia. One of the main authors of the book is Dr. Sibeso Luswata, a curriculum specialist and erstwhile UNICEF consultant on education. Dr. Luswata is a member of Northmead Assemblies of God, a prominent church in Lusaka with an internationally known choir and a weekly television broadcast carried by the Zambian National Broadcasting Company. ${ }^{58}$ Northmead is headed by Dr. Bishop Joshua Banda, a senior pentecostal leader and, more recently, a close confidant of Zambian President Edgar Lungu. Bishop Banda penned the foreword to Embracing our Destiny, which provides the theological orientation for the rest of the book. Using the Seven Mountains model as his guide, Banda evaluates Zambia's progress with regard to Christian influence; he

54 Quoted in Gifford, "Chiluba's Christian Nation," 367.

55 See Haynes, “'Zambia Shall be Saved!" for a detailed analysis of these discussions.

$5^{6}$ This covenantal view of Kaunda's government is also why it was so important that Kaunda publicly "released" the country "from every negative forces $[$ sic $]$ made against Zambia" in a widely publicized statement from 2015. See: https://www.lusakatimes.com/2015/05/26/ kk-prays-and-blesses-the-nation/. Accessed January 27, 2021.

57 Africa Arise, Embracing Our Destiny: Redeeming Zambia in Righteousness-Africa's Tithe (Nairobi: Asaph Office Publications, 2016).

58 See Adriaan van Klinken, Transforming Masculinities in African Christianity: Gender Controversies in Times of AIDS (New York: Routledge, 2016), 103-148, for more information on Northmead Assembly. 
is sanguine about the state of education and arts and entertainment, more circumspect about Christianity's role in shaping media and, perhaps surprisingly, religion, citing the expansion of "radical Islam" across Africa as a particular point of concern.

The rest of the book is also informed by NAR principles. Just as advocates of the Seven Mountains framework argue that transformation will be effected by individual Christians who step into their calling, the Africa Arise authors believe that God's calling for Zambia will help bring transformation to other nations. Their arguments in this regard echo broader trends in "neo-Pentecostal internationalism" which "charges certain nations with uniquely Christian responsibilities" in relationship to the rest of the world. ${ }^{59}$ Specifically, the Africa Arise authors argue that God has set aside their country as a "tithe" for the rest of the continent. They never spell out precisely what they mean by this concept, apart from the notion that what Zambia has to offer Africa will necessarily follow from what God has given the country, just as a tithe is a proportional gift, the amount of which is determined by one's income. ${ }^{60}$ By way of Zambia's endowments, the authors first cite the country's relatively unique history of interethnic peace, its well its established Christian tradition beginning with David Livingstone, and the welcome reception that those fleeing violence have always received in Zambia. They also draw particular attention to the country's natural resources, especially those that are underutilized (such as arable land and fresh water) or undiscovered (many Zambian Pentecostals believe, following well publicized prophetic words, that the country has untapped mineral and petroleum reserves that are far more extensive than what is currently being extracted). In view of its history and resources, the authors argue, drawing on the words of Charles Kachikoti, "Zambia has become a prized jewel among the great nations of the earth." ${ }^{61}$ Key to Zambia's ultimate success or failure to fulfill this destiny is the progress of Christians up the "business" mountain of influence, which the authors place on par with divinely ordained offices such as apostles and prophets. ${ }^{62}$ This emphasis on the economic sphere continues throughout the final chapter of the book, which focuses on strategies to help

59 Kevin Lewis O'Neill, City of God:Christian Citizenship in Postwar Guatemala (Berkeley: University of California Press, 2010), 172.

6o During an interview in 2017, I asked Dr. Luswata what it meant for Zambia to be Africa's "tithe," and at that point she emphasized that Zambia should be a leader, since it was the first (and as yet the only) African country to declare itself a Christian nation; the connection to tithing here may be in the idea of giving one's "first fruits" to God.

61 Africa Arise, Embracing our Destiny, 45 .

62 Africa Arise, Embracing our Destiny, 92. 
Zambia take its rightful place as Africa's tithe, and specifically on the willingness of Christian business people to "claim the economy" for Christ. ${ }^{63}$

While the authors examined here have clearly drawn on the ideas of Christian Reconstruction and NAR in developing their visions of what it means for Zambia to be a Christian nation, it is equally apparent that they have modified these ideas to reflect local perspectives and concerns. By way of a conclusion, I would like to examine further two key points of distinction between the Western theological models the authors employ and the particular arguments made by the latter in order to make a few brief observations about the varieties and forms of Christian nationalism operating in Zambia.

\section{Conclusion: North American Political Theology in a Zambian Key}

The first point to discuss is the shift from Christian Reconstructionism's dualistic division between God and humanity to an African pentecostal division between God and Satan, which clearly influenced Dr. Mukuka's understanding of how humanism shaped Zambia's destiny. Mukuka's pentecostal view builds on Rushdoony's argument that there is no such thing as neutrality, and ultimately raises the stakes of this claim by assigning control of non-Christian territory not to fallen humanity but to the evil workings of Satan. The comparison here is one between two different covenants, the divine covenant of the declaration, which promises peace and prosperity, and the predatory covenants of satanic pacts, which literally demand the lives of those caught in the middle of them. ${ }^{64}$ In this framing, there is not only no neutral territory, there is no safe place outside the declaration. This perspective, by extension, rejects the supposed neutrality of the secular liberalism that often undergirds arguments about the separation of church and state. Writing about postapartheid South Africa, John and Jean Comaroff note the seductive promise of liberal constitutions to "transmute difference into singularity" through appeals to global standards of human rights. ${ }^{65}$ Building on this observation, they argue that the unifying potential of liberalism, particularly insofar as it seeks to incorporate a broad range of cultural differences, is not so easily realized as its proponents imagined. Where Comaroff and Comaroff focus on culture, exemplified in their

63 Africa Arise, Embracing our Destiny, 102.

64 See Haynes, "'Zambia Shall be Saved!”

65 John L. Comaroff and Jean Comaroff, "Criminal Justice, Cultural Justice: The Limits of Liberalism and the Pragmatics Of Difference in the New South Africa," American Ethnologist 31 (2004): 192. 
argument in beliefs about witchcraft, parallel discussions of what they call the "limits of liberalism" have likewise emphasized the inability of rights-based legal structures to accommodate religious diversity. ${ }^{66}$ This is clear in the example of Christian Concern, a UK charity dedicated to defending the rights of Christians facing legal discrimination in an increasingly secular Britain. Cases taken by Christian Concern's legal team often highlight the legal stalemate of liberalism, which pits some rights (for example, those of religious conscience) against others (such as sexual expression) ${ }^{67}$ Taken together, these examples suggest conclusions that Rushdoony himself anticipated: that neutrality, in this case legal neutrality, is really nothing of the sort, and that outside of the framework of divine rule one was left to the judgments of humans-judgments that Christians and non-Christians alike often find unsatisfying. What the Zambian case further demonstrates, then, is the need for political, institutional, and legal categories beyond those found in the Western liberal tradition or, for that matter, in the framework of Christian Reconstruction.

Turning our attention to the Africa Arise volume, it is clear that for Zambian church leaders such as Bishop Banda, the social changes associated with their country's divine destiny hinge on economic transformation. While the book pays attention to all Seven Mountains of Influence, the mountain that the writers regard as the most crucial to conquer is neither the government nor religion, but rather business and the economy (recall that they put economic leaders on par with apostles and prophets). This view suggests that for church leaders (and in my experience this holds for laypeople as well), Zambia's spiritual development is inextricably linked to the country's economic progress. Given the widespread influence of the prosperity gospel on Zambian Christianity over the last twenty years, ${ }^{68}$ this is not surprising. When we read this emphasis back onto the theological models that Zambian Christians are using, we see a very different critical framework from that which we typically associate with Christian nationalism in the West. To wit, while political critiques that focus on economic problems are not uncommon in Christian circles, they are often absent from the conservativism that animates most Christian nationalism, at

66 See, for example, Saba Mahmood, Religious Difference in a Secular Age: A Minority Report (Princeton: Princeton University Press, 2016); Méadhbh McIvor, "Human Rights and Broken Cisterns: Counterpublic Christianity and Rights-based Discourse in Contemporary England," Ethnos 84 (2019): 323-343.

67 See McIvor, "Human Rights and Broken Cisterns"; Méadhbh McIvor, "Rights and Relationships: Rhetorics of Religious Freedom among English Evangelicals," Journal of the American Academy of Religion 87 (2019): 86o-888. 
least in the United States. In contrast, Zambian Christian nationalists see very clearly that the key to social change in their country is economic change.

This observation returns us to the vexed question of LGBT rights with which our discussion began, and more specifically to accusations of undue Western influence in shaping anti-gay legislation in Africa. A recent exposé on the South African website The Daily Maverick singled out Zambia's ambassador to the African Union, Emmanuel Mwamba, for his public opposition to "comprehensive sexuality education" (CSE). ${ }^{69}$ Mwamba has been publicly skeptical of CSE in part because of its acceptance of homosexuality, a position that his critics connect to Mwamba's relationship with Family Watch International, an American Christian NGo. While it is not difficult to believe that the ambassador's opinions have been influenced by his connection to Western conservative Christianity, in view of the foregoing discussion we might ask whether there is more to the story than the simple one-way influence of powerful international donors. In an Op-Ed making his case against the rollout of CSE in Zambia, Mwamba calls for the money that would be spent on this initiative to be used instead to support what he calls "comprehensive entrepreneurship education" for young people. ${ }^{70}$ Mwamba's article is not just a call to shift the financial priorities of overseas charities, or even a criticism of Western liberal sexual ethics. By echoing Zambian church leaders' reorientation of the Seven Mountains model around economic empowerment, Mwamba's piece can also be read as a call for national, divinely mandated movement toward Zambia's national destiny as "Africa's tithe." Insofar as this is the case, his critique of CSE is shaped by local theological adaptations, even as it is also clearly influenced by the concerns of conservative American Christians. ${ }^{71}$ At play in Mwamba's rejection of CSE, then, are several lines of critical interrogation, now accepting, now pushing back, now modifying the ideas and concerns of transnational

69 Kerry Cullinan, Zarina Geloo, and Tuyeimo Haidula, "American Christian Right Group Hosts Anti-LG BT Training for African Politicians," The Daily Maverick, October 27, 2020. https://www.dailymaverick.co.za/article/2020-10-27-american-christian-right-group-hos ts-anti-lgbt-training-for-african-politicians/?fbclid=IwAR2PmJkdeCLMMCLAhFBKRDU x-B6knR5IPCUiS6cKZGRCyuDgJWPNUngWOTw, accessed January 27, 2021.

70 Emmanuel Mwamba, "Op-Ed: Entrepreneurship or Sex Education, Where Should Our Focus Be?" The Independent Observer, September 22, 2020, https://tiozambia.com/op-ed -entrepreneurship-or-sex-education-where-should-our-focus-be/?fbclid=IwARoLigXQF Fr849Lk27vbR_qo5vjCoZWooHms_peQEfaoVRDaX37GJzX_upo, accessed January 27, 2021.

71 This complex blend of critique and adaptation is also evidenced in the parallel Mwamba draws between CSE and structural adjustment, an externally imposed initiative that had drastic consequences for the economies of Zambia and many other African countries. 
Christian actors. These moves are subtle and therefore easy to miss, but they are important to anyone wishing to understand the public face of contemporary African Christianity.

Clearly, theological ideas with Western roots have had an important part to play in shaping the contours of Christian nationalism in contemporary Zambia. What the foregoing analysis has also demonstrated, however, is that even subtle shifts in content or emphasis have significant implications for the way in which church and state leaders approach religious politics in Africa's only self-declared Christian nation. Future research on Christian politics around the world, but perhaps especially in postcolonial contexts, will therefore require a careful balance of rigorous textual engagement with primary sources that may have traveled to the context under study through transnational networks, with careful ethnographic and literary study to demonstrate how these sources are taken up. Such efforts represent important contributions to "fine-grained ethnographic discussions that can flesh out the contours of ... the Christian nationalist problem,"72 to return to Bialecki's words. It is only through analysis of this kind that we are able to avoid reductive arguments about the outsized influence of the West. In other words, it is only through a careful, ethnographically grounded reading of Christian nationalist movements that we are able to effectively map the theological influences shaping Christian politics, as well as the unique ways in which local Christian communities are working with these theological ideas to respond to their particular concerns.

72 Bialecki, "Eschatology, Ethics, and Ëthnos," 46. 